\title{
Solar Cell Fabrication Using Two-step Textured Quasi-single Crystalline Silicon by Alkaline and RIE Texturing Processes
}

\author{
Jinsu Yoo ${ }^{\text {ab }}$, Kyu-Min $\operatorname{Han}^{\mathrm{c}}$ and Jun-Sik Cho ${ }^{\text {ab* }}$ \\ ${ }^{a}$ Photovoltaic Laboratory, Korea Institute of Energy Research, 102 Gajeong-ro, \\ Yuseong-gu, Daejeon, 305-343, Republic of Korea \\ ${ }^{b}$ Department of Renewable Energy Engineering, University of Science and Technology, \\ 217 Gajeong-ro, Yuseong-gu, Daejeon, 305-350, Republic of Korea \\ ${ }^{c}$ Department of Electronics Engineering, Chungnam National University, 99 Daehak-ro, \\ Yusong-gu, Daejeon, 305-764, Republic of Korea
}

\begin{abstract}
After alkaline chemical texturing process, $\mathrm{SF}_{6} / \mathrm{O}_{2}$ reactive ion etching (RIE) was used for maskless textured Si surface independently from crystal orientation. Additional RIE texturing on alkaline textured $\mathrm{Si}$ surface increased the light receiving areas and decreased the surface reflectance by random pyramidal structures with a width of hundreds of nanometers. The weighted average reflectance (WAR) of the textured $\mathrm{Si}$ surface by two-step texturing processes was achieved as low as $9.6 \%$ in the $300-1200$
\end{abstract}


nm wavelength range. Compared to the alkaline texturing, the alkaline and RIE texturing of front Si surfaces decreased the WAR by 6\%. By means of two-step texturing processes for quasi-single crystalline silicon (QSC-Si) surfaces, performance parameters of the solar cell such as conversion efficiency, short circuit current density $\left(\mathrm{J}_{\mathrm{sc}}\right)$, open circuit voltage $\left(\mathrm{V}_{\mathrm{oc}}\right)$ and fill factor $(\mathrm{FF})$ were examined in $18.2 \%, 36.6$ $\mathrm{mA} / \mathrm{cm}^{2}, 624 \mathrm{mV}$ and $79.7 \%$, respectively.

Keywords: Light Trapping, Quasi-single Crystalline Silicon, Reactive Ion Etching, Surface Reflectance, Conversion Efficiency

*Corresponding author: Email- jscho@kier.re.kr

Tel.: +82-42-860-3214; Fax: + 82-42-860- 3692 
Photovoltaic cells are one of the most promising devices which directly convert sunlight into electricity. The crystalline silicon (c-Si) solar cells are the most extensively commercialized solar cells and have increased over $90 \%$ global solar cell market share in photovoltaic industry [1-4]. The two main types of c-Si used in solar cell fabrication are monocrystalline (mono-Si) and multicrystalline silicon (mc-Si). The mono-Si is manufactured by the process technologies such as Czochralski (CZ), Float Zone (FZ) and Bridgeman method [5-9]. Also, mc-Si is grown by the casting and heat exchange methods $[10,11]$. The mc-Si has high levels of contamination by the reaction with various contaminants during manufacturing processes using high temperature and high crystal defect content such as sub-grain boundaries, grain boundaries and dislocations [12-14]. Therefore, the mc-Si solar cell efficiency shows much lower than that made of mono-Si due to take effect in impurities and crystal defects $[15,16]$. Nevertheless, the casting methods for growing mc-Si are widely used for solar cell fabrication due to the strength of higher throughputs, lower manufacturing costs and simpler processes in comparison to the $\mathrm{CZ}$ technique [17]. The crystal defects and impurities of mc-Si materials which are manufactured by relatively uncomplicated and cost-effective techniques can be solved by combination of the high purity levels connected with mono-Si processing. Quasi-single crystalline silicon (QSC-Si) known as quasi-mono or 
mono-like $\mathrm{Si}$ is a relatively new PV technology that has met these requirements and has received much interest in the PV industry recently [18]. This material is positioned between mono-Si and mc-Si in respect of crystalline quality, production cost and solar cell efficiency. The crystallographic orientation of QSC-Si was formed from both $<111>$ and $<100>$ orientations. In addition, QSC-Si has good structural and electrical properties by improving the crystal quality and controlling the defects. Therefore, this material is very effective in reducing the cost of solar cell fabrication due to its ability to form thinner wafers and its better mechanical strength, resulting in faster processing [19-25]. In this work, we observed the QSC-Si surface morphology by two-step texturing processes using alkaline chemical and reactive ion etching (RIE) to achieve higher efficiency of solar cells by reducing the surface reflectance for optimization of light-trapping effects within the cell.

The boron-doped p-type QSC-Si wafers were used with an average thickness of $200 \mu \mathrm{m}$, a resistivity of $1-3 \Omega \cdot \mathrm{cm}$ and a size of $156 \times 156 \mathrm{~mm}^{2}\left(243.3 \mathrm{~cm}^{2}\right)$ for solar cell fabrication. To remove the contamination of Si surface, the wafer was cleaned by the solution containing deionized water (DIW) and $\mathrm{KOH}(1 \mathrm{wt} \%)$ in an ultrasonic environment of $40-50 \mathrm{kHz}$ for $8 \mathrm{~min}$ at $25^{\circ} \mathrm{C}$. Also, alkaline texturing process on the wafer surfaces was carried out by mixed solutions $\mathrm{KOH}(1.2 \mathrm{wt} \%)$, IPA (6-8 wt\%) and 
$\mathrm{DIW}$ at $80^{\circ} \mathrm{C}$ for $13 \mathrm{~min}$. After alkaline texturing, the $\mathrm{Si}$ wafers were placed on power electrode of water-cooled type below $20^{\circ} \mathrm{C}$ in parallel-plate reactor with $\mathrm{RF}$ (13.56 $\mathrm{MHz}$ ) generator at a base pressure of $0.075 \mathrm{~Pa}$. The $\mathrm{SF}_{6}$ and $\mathrm{O}_{2}$ gases were mixed and fed into the Process chamber. In this work, RIE surface texturing was performed at a working pressure of $1.13 \mathrm{~Pa}, \mathrm{SF}_{6}: \mathrm{O}_{2}$ gas ratio of $6: 5$ and a $\mathrm{RF}$ power of $4 \mathrm{~kW}$ for $6 \mathrm{~min}$. The $\mathrm{n}^{+}$emitter was formed by phosphorus diffusion using Phosphorus oxychloride $\left(\mathrm{POCl}_{3}\right)$ source in a furnace with the temperature at $840{ }^{\circ} \mathrm{C}$ to obtain the sheet resistance ranged from 60 to $65 \Omega /$ square. As an antireflection coating, the hydrogenated silicon nitride $(\mathrm{SiNx}: \mathrm{H})$ layers were prepared by plasma enhanced chemical vapor deposition (PECVD) method at a temperature of $400{ }^{\circ} \mathrm{C}$. The reflective index and the film thickness of $\mathrm{SiNx}: \mathrm{H}$ layers were about 2.1 and from 80 to $82 \mathrm{~nm}$, respectively. The metallic contact of the front and back Si surfaces was formed by Silver (Ag) and aluminum (Al) paste screen printing. After the drying process for these pastes at $150{ }^{\circ} \mathrm{C}$ for $5 \mathrm{~min}$, the Si wafers were subjected to co-firing cycle in IR-lamp-heated belt furnace for hightemperature sintering. Finally, the edge isolation process by laser technique was used for preventing any possibility of short-circuiting the p-n junction through the edges of the Si wafers.

Morphologies and compositions of the Si surface were examined by field emission 
scanning electron microscopy (FESEM, Hitachi S4700, Japan at $10 \mathrm{kV}$ ), and energy dispersive spectroscopy (EDS, EDAX Genesis apex, acceleration voltage: $30 \mathrm{kV}$, collection time: $100 \mathrm{~s}$ with standardless method), respectively. The textured Si surface reflectance was investigated by UV-VIS spectrophotometer (UV-vis, Shimadzu Japan, UV-VIS-NIR 3101) with an integrating sphere in the 300-1200 nm wavelength range. The electrical sheet resistance (Rs) of the $\mathrm{n}+$ emitter layer was analyzed by a four-point probe (MCP-T610, Mitsubishi Chemical, Japan). The minority carrier lifetime measurements were carried out with a $\mu$-PCD system from Semilab (WT-1000), which measured the lifetime to a precision of $\pm 0.01 \mu \mathrm{s}$. External quantum efficiency (EQE) was investigated by using an IPCE(incident photon conversion efficiency) measurement unit (PV Measurements, Inc., USA). The Illuminated current-voltage (I-V) curve of Si solar cells was characterized by a solar simulator (94082A, Newport, USA) at $25^{\circ} \mathrm{C}$ under $100 \mathrm{mWcm}^{-2}$ illumination (AM $\left.1.5 \mathrm{G}\right)$.

Due to a $<100>$-oriented seed crystals, the grown QSC-Si ingot is formed mostly from $\langle 100\rangle$-oriented single crystals. But mc-Si is unavoidably generated at part of the QSC-Si ingots in mass production line by reason of the shape defects of the solidification interface and free nucleation on the crucible walls during the solidification process [26]. Fig. 1 shows the optical image of as-cut wafer with a size of $156 \times 156$ 
$\mathrm{mm}^{2}\left(243.3 \mathrm{~cm}^{2}\right)$ for solar cell fabrication and the SEM images of QSC-Si surface morphologies. As shown in Fig. 1(a), the wafer consists of the $\langle 100\rangle$-oriented single crystal and mc-Si areas. QSC-Si surface of Fig. 1(b) with the $<100\rangle$-oriented single crystal has the same surface structure as that of conventional CZ-Si wafer. The increase in single crystals ratio of QSC-Si wafer has an effect on the improvement of solar cell efficiency [26]. Therefore, the QSC-Si wafers with a single crystal ratio of more than $90 \%$ were used for application of high-efficiency solar cell fabrication in this work. To improve the light-trapping effect for solar cells, the $\langle 100\rangle$-oriented single CZ-Si is usually textured by the anisotropic alkaline texturing technique, while the surface structure for reducing reflectance can be achieved in mc-Si wafers by using isotropic acidic or RIE texturing due to their random orientation of crystal grains [27-29].

After Saw damage removal (SDR) process, alkaline texturing was carried out for formation of uniform pyramid structures in the $\langle 100\rangle$-oriented single crystal surface with a single crystal ratio of more than $90 \%$. RIE process using $\mathrm{SF}_{6} / \mathrm{O}_{2}$ as etch gases was also used for mask-less surface texturing of mc-Si areas which was polished by alkaline texturing. SEM images of surface morphology for the $\langle 100\rangle$-oriented single crystal and mc-Si areas textured by alkaline and RIE process are shown in Fig. 2. Fig. 2(a) shows a homogenous pyramidal structures of the $\langle 100\rangle$-oriented single crystal by 
alkaline texturing technology. After the wet chemical alkaline texturing, RIE method forms the regular and dense surface structures on alkaline textured single crystal areas as shown in Fig. 2(b). The mc-Si areas polished by alkaline texturing are shown in Fig. 2(c). RIE-textured mc-Si surface is covered in random pyramidal structures with the RMS roughness of $115 \mathrm{~nm}$ as shown in Fig. 2(d). As a result, the RIE texturing technique has an effect on improving the trapping of incident light due to the formation of pyramidal structures with a width of hundreds of nanometers on alkaline textured single crystal and mc-Si areas. The atomic percent of silicon and oxygen is investigated by EDS analysis of QSC-Si surface. Based on the etch mechanism of strong sidewall passivation by adsorbed $\mathrm{Si}_{\mathrm{x}} \mathrm{O}_{\mathrm{y}} \mathrm{F}_{\mathrm{z}}$ layers, the oxygen atomic percent of $5.8 \%$ in RIEtextured QSC-Si surface has an influence on the morphological properties of the random pyramidal structure during the RIE process. In plasma chemistry and reaction mechanism during a $\mathrm{SF}_{6} / \mathrm{O}_{2} \mathrm{RIE}$ process, $\mathrm{SF}_{6}$ produces $\mathrm{F}^{*}$ radicals to use a chemical etching process of $\mathrm{c}-\mathrm{Si}$ by forming volatile silicon tetrafluoride $\left(\mathrm{SiF}_{4}\right)$. Oxygen forms O* radicals for the passivation of $\mathrm{Si}$ sidewall surfaces with $\mathrm{Si}_{\mathrm{x}} \mathrm{O}_{\mathrm{y}} \mathrm{F}_{\mathrm{z}}$ which has an effect on the control of etch profiles. The walls of the random pyramidal structures are covered with adsorbed $\mathrm{Si}_{\mathrm{x}} \mathrm{O}_{\mathrm{y}} \mathrm{F}_{\mathrm{z}}$ and are somewhat protected against etching. [30-35].

Reflectance spectra of QSC-Si surface with various kinds of surface conditions by 
alkaline and RIE texturing processes are shown in Fig. 3. Prior to alkaline texturing process, the bare QSC-Si wafer was cleaned by SDR process which was performed by the solution containing DIW and $\mathrm{KOH}(1 \mathrm{wt} \%)$. The average reflectance of 30.6 and $15.6 \%$ measured in the wavelength range of 300 to $1200 \mathrm{~nm}$ was examined for bare and alkaline-textured QSC-Si surface, respectively. Compared to these measured values, the minimum average reflectance of 9.5\% was investigated for RIE-textured QSC-Si surface on alkaline-textured wafer. As mentioned above, the oxygen atomic percent is related to the random pyramidal structure by the observed $\mathrm{Si}_{\mathrm{x}} \mathrm{O}_{\mathrm{y}} \mathrm{F}_{\mathrm{z}}$ layers which are covered with QSC-Si sidewall surface. These masking layers are just enough to be kept as a randomly perforated mask during RIE texturing. As a result of the pyramidal structure formed by two-step texturing processes, the optical reflectance decreased dramatically for enhancing the light-trapping effect by the increased surface area involved in the light absorption.

The comparison of minority carrier lifetimes in alkaline textured and alkaline and RIE textured QSC-Si by each sequential step in solar cell fabrication processes is shown in Fig. 4. As individual solar cell fabrication steps progress, the minority carrier lifetimes which was measured in the same values for two types of bare QSC-Si wafers increased. After solar cell manufacturing processes such as texturing, diffusion and 
hydrogenated silicon nitride $(\mathrm{SiNx}: \mathrm{H})$ deposition processes, the minority carrier lifetimes of alkaline and RIE textured wafers were improved more than those of alkaline textured wafers. These values of $0.8 \mu$ s for bare QSC-Si wafers increased about 16.1 $\mu \mathrm{S}$ and $19.8 \mu \mathrm{S}$ respectively for alkaline textured and alkaline and RIE textured QSCSi after the SiNx:H deposition by using PECVD systems. The minority carrier lifetimes by additional RIE texturing increased as solar cell fabrication steps from $0.3 \mu$ s to 3.77 $\mu \mathrm{s}$. Due to the reduction in surface recombination velocity, the major effect on improving the minority carrier lifetime of QSC-Si is involved in increasing solar cell efficiency.

External quantum efficiencies (EQE) spectra and illuminated current-voltage (LIV) curves for QSC-Si solar cell are shown in Fig. 5. Fig. 5(a) shows the EQE spectra in 300-1200 nm wavelength range for alkaline textured and alkaline and RIE textured QSC-Si solar cells. According to the decrease in the surface recombination for the improvement of optical and electrical properties, the EQE analysis of the alkaline textured QSC-Si solar cell has a poor response for all wavelengths compared to that of alkaline and RIE textured QSC-Si solar cell. Therefore, additional RIE texturing on alkaline textured wafer has an effect on enhanced light-trapping in solar cells by the fine and dense pyramidal surface structures with a width of hundreds of nanometers. 
Illuminated current-voltage (LIV) curves for QSC-Si solar cell fabricated by sequential process of alkaline and RIE surface texturing are shown in Fig. 5(b). After RIE texturing process on alkaline textured wafer, the open circuit voltage $\left(\mathrm{V}_{\mathrm{oc}}\right)$, short circuit current density $\left(\mathrm{J}_{\mathrm{sc}}\right)$ and fill factor $(\mathrm{FF})$ of solar cell increased about $1 \mathrm{mV}, 1.4 \mathrm{~mA} / \mathrm{cm}^{2}$ and $1.1 \%$ compared to that of alkaline textured solar cell. The solar cell conversion efficiency of $18.2 \%$ was obtained by the increase in these electrical performance parameters.

In summary, due to high-rate crystal growth by enhanced productivity, mechanical stability and lower impurities, the QSC-Si is very promising material in manufacturing cost reduction for silicon solar cell. In this work, we performed the surface texturing processes for the formation of pyramidal structures in the $\langle 100\rangle$-oriented single crystal and mc-Si areas of QSC-Si wafer. To satisfy the surface morphology of these two areas, RIE texturing process was used as following process of conventional alkaline texturing. Additional RIE texturing on alkaline textured QSC-Si wafer decreased in optical reflectance and improved the minority carrier lifetimes by random pyramidal structure for increasing solar cell efficiency. The best $156 \times 156 \mathrm{~mm}^{2}\left(243.3 \mathrm{~cm}^{2}\right)$ QSC-Si solar cell fabricated by two-step texturing processes showed $\mathrm{J}_{\mathrm{sc}}=36.6 \mathrm{~mA} / \mathrm{cm}^{2}, \mathrm{~V}_{\mathrm{oc}}=624 \mathrm{mV}$, $\mathrm{FF}=79.7 \%$ and conversion efficiency $=18.2 \%$. 


\section{ACKNOWLEDGEMENT}

This work was supported by the Global Frontier R\&D Program on Center for Multiscale

Energy System funded by the National Research Foundation under the Ministry of Science, ICT \& Future, Korea (2011-0031567). This work was also conducted under the framework of Research and Development Program of the Korea Institute of Energy Research (KIER) (B6-2419). 


\section{References}

[1] W. Li, T. Wu, R. Jiao, B. -P. Zhang, S. Li, Y. Zhou, L. Li, Effects of silver nanoparticles on the firing behavior of silver paste on crystalline silicon solar cells, Colloids and Surfaces A: Physicochem. Eng. Aspects 466 (2015) 132-137.

[2] S. Mathew, A. Yella, P. Gao, R. Humphry-Baker, B. F. E. Curchod, N. AshariAstani, I. Tavernelli, U. Rothlisberger, M. K. Nazeeruddin, M. Grätzel, Dye-sensitized solar cells with $13 \%$ efficiency achieved through the molecular engineering of porphyrin sensitizers, Nat. Chem. 6 (2014) 242-247.

[3] D. Liang, Y. Kang, Y. Huo, Y. Chen, Y. Cui, J. S. Harris, High-efficiency nanostructured window GaAs solar cells, Nano Lett. 13 (2013) 4850-4856.

[4] T. Saga, Advances in crystalline silicon solar cell technology for commercial mass production, NPG Asia Mater. 2 (2010) 96-102

[5] C. Wang, H. Zhang, T. H. Wang, T. F. Ciszek, A continuous Czochralski silicon crystal growth system, J. Cryst. Growth 250 (2003) 209-214.

[6] V. V. Kalaev, I. Yu. Evstratov, Yu. N. Makarov, Gas flow effect on global heat transport and melt convection in Czochralski silicon growth, J. Cryst. Growth 249 (2003) 87-99. 
[7] M. Trempa, C. Reimann, J. Friedrich, G. Muller, D. Oriwol, Mono-crystalline growth in directional solidification of silicon with different orientation and splitting of seed crystals, J. Cryst. Growth 351 (2012) 131-140.

[8] H. Nakazawa, M. Ogino, H. Teranishi, Y. Takahashi, H. Habuka, Precipitates caused by prolonged high-temperature annealing in floating zone silicon wafer grown from Czochralski single-crystal rod, Mat. Sci. Semicon. Proc. 16 (2013) 923-927.

[9] K. Surovovs, A. Muiznieks, A. Sabanskis, J. Virbulis, Hydrodynamical aspects of the floating zone silicon crystal growth process, J. Cryst. Growth 401 (2014) 120-123.

[10] F. Huang, R. Chen, J. Guo, H. Ding, Y. Su, J. Yang, H. Fu, Feasibility of directional solidification of silicon ingot by electromagnetic casting, Mat. Sci. Semicon. Proc. 15 (2012) 380-385.

[11] E. V. Zharikov, Problems and recent advances in melt crystal growth technology, J. Cryst. Growth 360 (2012) 146-154.

[12] A. Jouini, D. Ponthenier, H. Lignier, N. Enjalbert, B. Marie, B. Drevet, E. Pihan, C. Cayron, T. Lafford, D. Camel, Improved multicrystalline silicon ingot crystal quality through seed growth for high efficiency solar cells, Prog. Photovolt. Res. Appl. 20 (2012) 735-746.

[13] L. Gong, F. Wang, Q. Cai, D. You, B. Dai, Characterization of defects in mono-like 
silicon wafers and their effects on solar cell efficiency, Sol. Energy Mater. Sol. Cells 120 (2014) 289-294.

[14] X. Gu, X. Yu, K. Guo, L. Chen, D. Wang, D. Yang, Seed-assisted cast quasi-single crystalline silicon for photovoltaic application: Towards high efficiency and low cost silicon solar cells, Sol. Energy Mater. Sol. Cells 101 (2012) 95-101.

[15] G. Stokkan, Relationship between dislocation density and nucleation of multicrystalline silicon, Acta Materialia 58 (2010) 3223-3229

[16] D. Sarti, R. Einhaus, Silicon feedstock for the multi-crystalline photovoltaic industry, Sol. Energy Mater. Sol. Cells 72 (2002) 27-40.

[17] B. Wu, N. Stoddard, R. Ma, R. Clark, Bulk multicrystalline silicon growth for photovoltaic (PV) application, J. Cryst. Growth 310 (2008) 2178-2184.

[18] M. G. Tsoutsouva, V. A. Oliveira, D. Camel, J. Baruchel, B. Marie, T. A. Lafford, Mono-like silicon ingots grown on low angle misoriented seeds: Defect characterization by synchrotron X-ray diffraction imaging, Acta Materialia 88 (2015) 112-120.

[19] K. Kutsukake, N. Usami, Y. Ohno, Y. Tokumoto, I. Yonenaga, Control of Grain Boundary Propagation in Mono-Like Si: Utilization of Functional Grain Boundaries, Appl. Phys. Express 6 (2013) 025505.

[20] N. Stoddard, B. Wu, I. Witting, M. Wagener, Y. Park, G. Rozgonyi, R. Clark, 
Casting single crystal silicon: novel defect profiles from BP Solars Mono ${ }^{2 \mathrm{TM}}$ wafers, Solid State Phenom. 131 (2008) 1-8.

[21] W. Ma, G. Zhong, L. Sun, Q. Yu, X. Huang, L. Liu, Influence of an insulation partition on a seeded directional solidification process for quasi-single crystalline silicon ingot for high-efficiency solar cells, Sol. Energy Mater. Sol. Cells 100 (2012) 231-238.

[22] K. M. Han, J. S. Cho, J. S. Yoo, Monocrystalline-like silicon solar cells fabricated by wet and dry texturing processes for improving light-trapping effect, Vacuum 115 (2015) 85-88

[23] A. Black, J. Medina, A. Piñeiro, E. Dieguez, Optimizing seeded casting of monolike silicon crystals through numerical simulation, J. Cryst. Growth 353 (2012) 12-16.

[24] T. Kaden, K. Petter, R. Bakowskie, Y. Ludwig, R. Lantzsch, D. Raschke, S. Rupp, T. Spiess, Analysis of mono-cast silicon wafers and solar cells on industrial scale, Energy Procedia 27 ( 2012 ) 103-108.

[25] B. Gao, S. Nakano, H. Harada, Y. Miyamura, T. Sekiguchi, K. Kakimoto, Reduction of polycrystalline grains region near the crucible wall during seeded growth of monocrystalline silicon in a unidirectional solidification furnace, J. Cryst. Growth 352 (2012) 47-52. 
[26] G. Zhong, Q. Yu, X. Huang, L. Liu, Performance of solar cells fabricated from cast quasi-single crystalline silicon ingots, Sol. Energy 111 (2015) 218-224.

[27] R. Barrio, N. González, J. Cárabe, J. J. Gandía, Optimisation of $\mathrm{NaOH}$ texturisation process of silicon wafers for heterojunction solar-cells applications, Sol. Energy 86 (2012) 845-854.

[28] Y.-T. Cheng, J.-J. Ho, S.-Y. Tsai, Z.-Z. Ye, W. Lee, D.-S. Hwang, S.-H. Chang, C.-C. Chang, K. L. Wang, Efficiency improved by acid texturization for multicrystalline silicon solar cells, Sol. Energy 85 (2011) 87-94.

[29] H. Jansen, M. de Boer, H. Wensink, B. Kloeck, and M. Elwenspoek, The black silicon method. VIII. A study of the performance of etching silicon using SF6/O2-based chemistry with cryogenical wafer cooling and a high density ICP source, Microelectron. J. 32 (2001) 769-777.

[30] G. Kumaravelu, M. M. Alkaisi, A. Biattar, Surface texturing for silicon solar cells using reactive ion etching technique, Proc. $29^{\text {th }}$ IEEE Photovolt. Specialists Conf., New Orleans, 2002, 258-261.

[31] T. Wells, M. M. El-Gomati, J. Wood, Low temperature reactive ion etching of silicon with $\mathrm{SF}_{6} / \mathrm{O}_{2}$ plasmas, J. Vac. Sci. Technol. B 15 (1997) 434-438.

[32] L. L. Tezani, R. S. Pessoa, H. S. Maciel, G. Petraconi, Chemistry studies of 
$\mathrm{SF}_{6} / \mathrm{CF}_{4}, \mathrm{SF}_{6} / \mathrm{O}_{2}$ and $\mathrm{CF}_{4} / \mathrm{O}_{2}$ gas phase during hollow cathode reactive ion etching plasma, Vacuum, 106 (2014) 64-68.

[34] S. Liu, X. Niu, W. Shan, W. Lu, J. Zheng, Y. Li, H. Duan, W. Quan, W. Han, C. R. Wronski, D. Yang, Improvement of conversion efficiency of multicrystalline silicon solar cells by incorporating reactive ion etching texturing, Sol. Eng. Mater. Sol. Cells 127 (2014) 21-26.

[35] J. S. Yoo, J. S. Cho, S. J. Ahn, J. H. Gwak, A. Cho, Y. J. Eo, J. H. Yun, K. H. Yoon, J. Yi, Random reactive ion etching texturing techniques for application of multicrystalline silicon solar cells, Thin Solid Films, 546 (2013) 275-278. 


\section{List of Figure}

Fig. 1. (a) Optical image of as-cut wafer and (b) SEM images of QSC-Si Si surface morphologies.

Fig. 2. SEM images of (a, c) alkaline-textured QSC-Si surface on bare wafers and (b, d)

RIE- textured QSC-Si surface on alkaline-textured wafers in the $<100>$-oriented single crystal and mc-Si areas.

Fig. 3. Reflectance spectra of QSC-Si surface with various kinds of surface conditions by alkaline and RIE texturing processes measured in the wavelength range of 300 to $1200 \mathrm{~nm}$.

Fig. 4. Comparative analysis on the minority carrier lifetimes of alkaline textured and alkaline and RIE textured QSC-Si by each sequential step in solar cell fabrication processes.

Fig. 5. (a) External quantum efficiencies (EQE) spectra and (b) illuminated currentvoltage (LIV) curves for QSC-Si solar cell fabricated by sequential process of alkaline and RIE surface texturing 

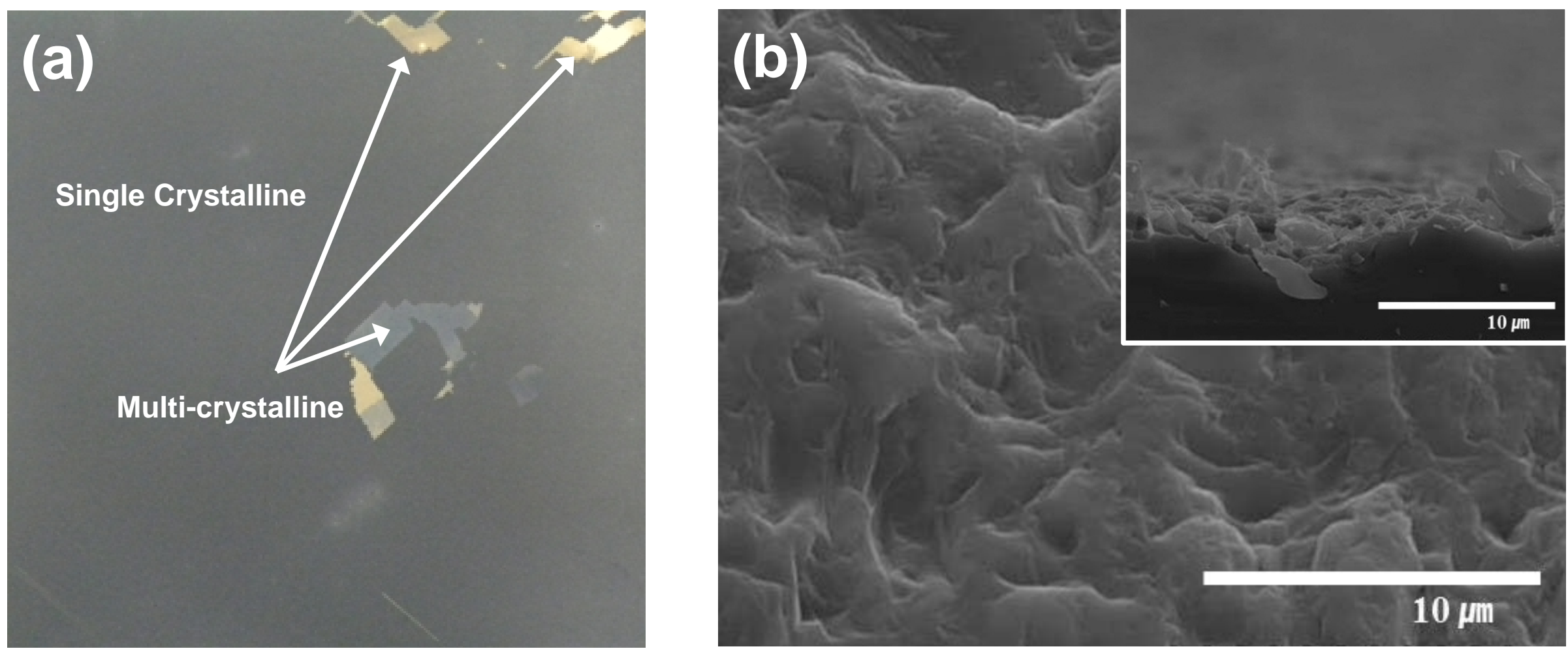

\section{Fig. 1. J. S. Yoo et al.




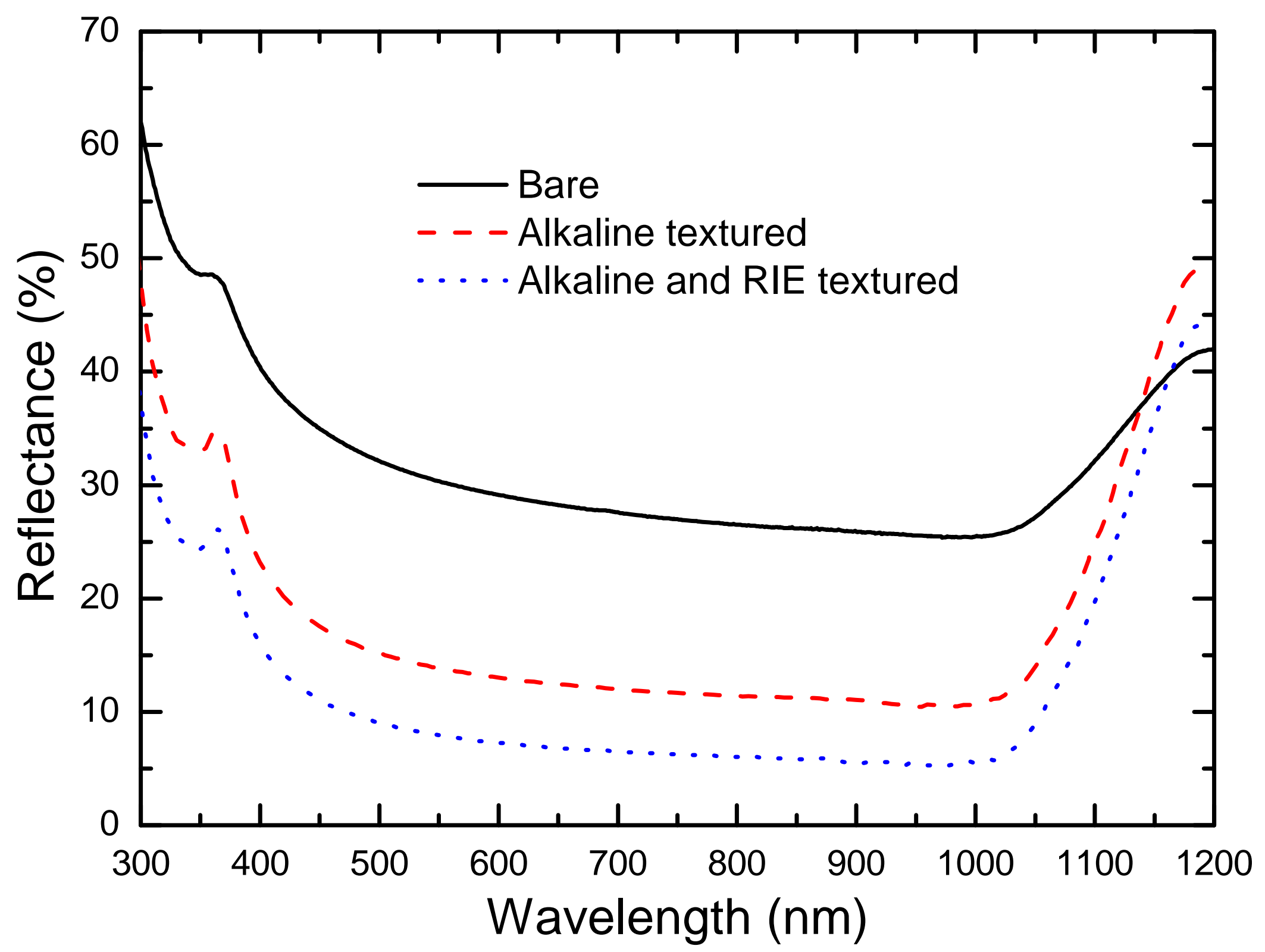

Fig. 3. J. S. Yoo et al. 


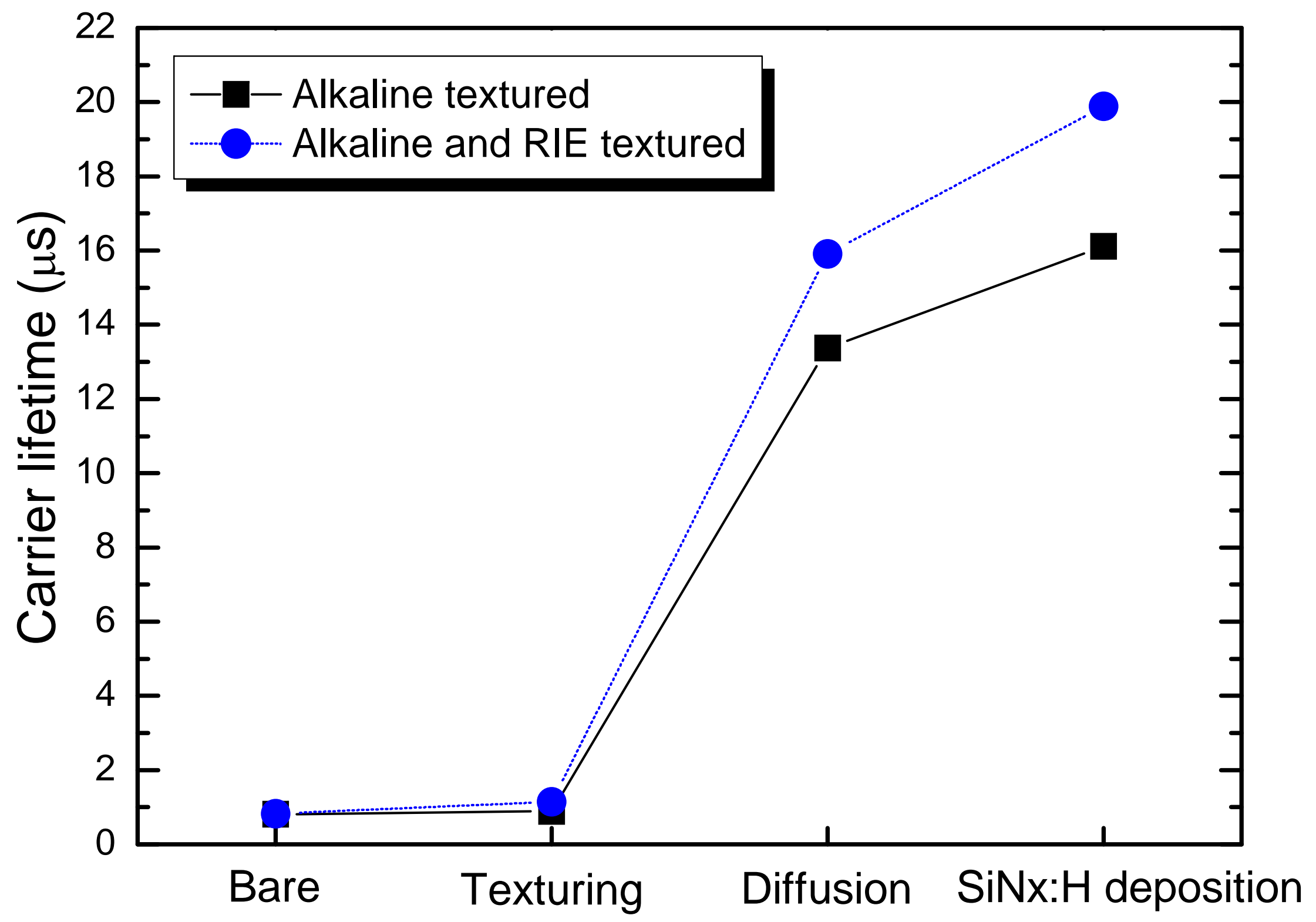

Fig. 4. J. S. Yoo et al. 

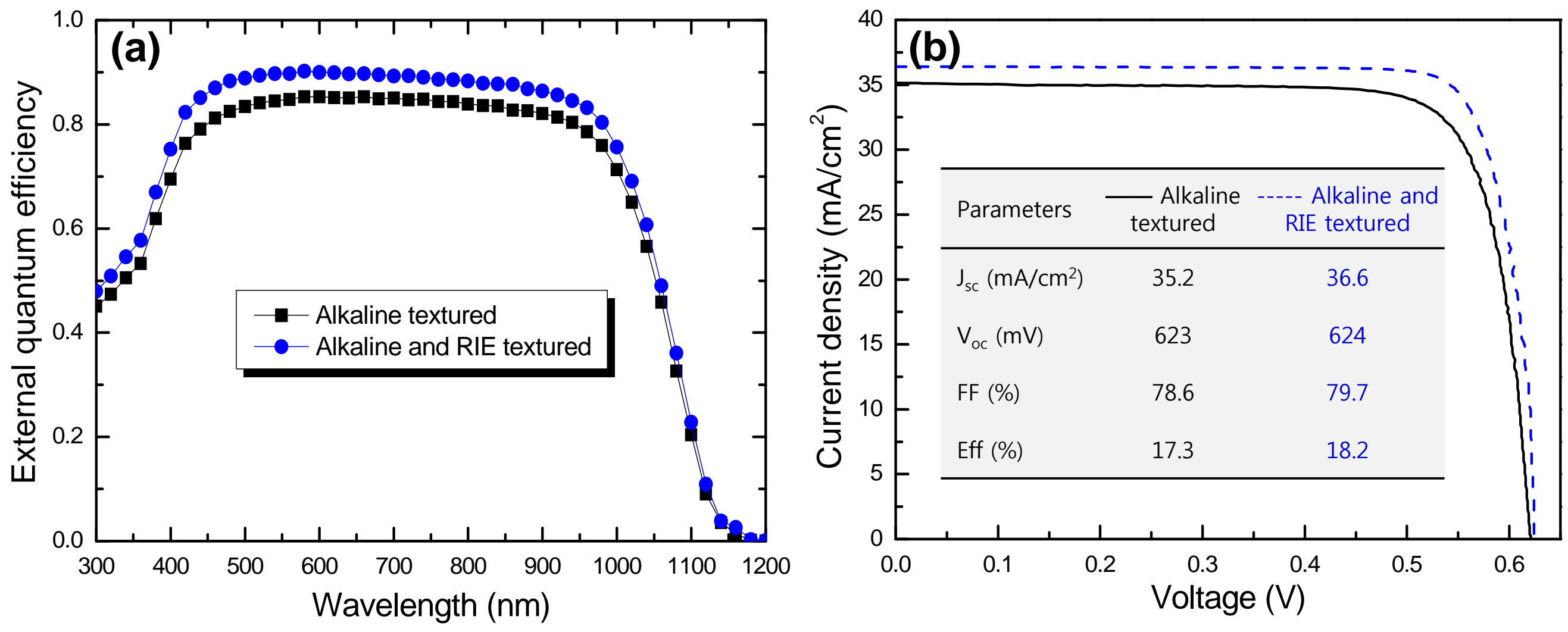

Fig. 5. J. S. Yoo et al. 